\title{
Cytochrome P4501A induction in oil-exposed pink salmon Oncorhynchus gorbuscha embryos predicts reduced survival potential
}

\author{
M. G. $\operatorname{Carls}^{1, *}$, R. A. Heintz ${ }^{1}$, G. D. Marty ${ }^{2,3}$, S. D. Rice ${ }^{1}$ \\ ${ }^{1}$ US National Marine Fisheries Service, Auke Bay Laboratory, 11305 Glacier Highway, Juneau, Alaska 99801, USA \\ ${ }^{2}$ Department of Anatomy, Physiology, and Cell Biology, School of Veterinary Medicine, University of California, Davis, \\ California 95616, USA
}

${ }^{3}$ Present address: Animal Health Centre, BCMAFF, 1767 Angus Campbell Road, Abbotsford, British Columbia V3G 2M3, Canada

\begin{abstract}
Cytochrome P4501A (CYP1A) induction in pink salmon Oncorhynchus gorbuscha embryos exposed to crude oil is linked to adverse effects at cellular, organism and population levels, and can be used to predict these responses. When combined with the results of an experiment designed to examine CYP1A induction during embryonic stages and growth after emergence, results from a series of experiments spanning 4 other brood years demonstrated that CYP1A induction is related to a variety of lethal and sublethal effects, including poorer marine survival, reduced growth and abnormalities. The lowest observed effective concentration of total polynuclear aromatic hydrocarbons (TPAH) in water that caused significant physiological responses, including reduced size 6 mo after exposure ended $\left(<0.94 \mu \mathrm{g} \mathrm{l}^{-1}\right)$, was less than the lowest concentration that caused significant CYP1A induction $\left(<3.7 \mu \mathrm{g} \mathrm{l}^{-1}\right)$. Thus, CYP1A induction is not only a biomarker, it can be considered a bioindicator; induction in early life stages implies long-term negative consequences for the individual and the population.
\end{abstract}

KEY WORDS: Cytochrome P4501A induction · PAH · Bioindicator · Biomarker · Embryo exposure · Pink salmon · Marine survival $\cdot$ Abnormalities

Resale or republication not permitted without written consent of the publisher

\section{INTRODUCTION}

Induction of mixed-function oxidase enzymes, such as cytochrome P4501A (CYP1A), in fish tissue as a result of exposure to axenic hydrocarbons has been used as evidence of exposure to oil (e.g. Wiedmer et al. 1996, Mondon et al. 2001, Hodson et al. 2002). Thus, CYP1A induction is useful as a biomarker, yet how it relates to long-term physiological responses was unknown before completion of the experiments described in this paper. For CYP1A to be considered a bioindicator, induction must be correlated with, or linked to, biological effects in the organism, population, community, or ecosystem (McCarty \& Munkittrick 1996). The distinction between biomarker and bioindicator is important and influences how environmental observations such as those of Wiedmer et al. (1996) are interpreted.

Previous research has linked CYP1A induction to short-term (weeks to months) adverse physiological responses of pink salmon embryos to oil but not to long-term (years) effects. CYP1A was induced at low TPAH concentrations (e.g. $4 \mu \mathrm{g} \mathrm{l}^{-1}$; Marty et al. 1997), and detrimental effects in fish embryos at similar levels have been demonstrated (Marty et al. 1997, Carls et al. 1999, Heintz et al. 1999, 2000, Barron et al. 2003). However, none of these experiments linked induction to long-term physiological consequences.

Our goal was to examine CYP1A induction as a predictor of short, intermediate and long-term biological consequences of embryonic exposure to oil. To accomplish this, pink salmon embryos were exposed to a 
graded series of low and exponentially declining oil doses beginning immediately after fertilization and ending 6 mo later at fry emergence. Measurement of CYP1A induction, survival and other responses continued long after exposure to determine delayed impacts. Survival was assessed at eyeing and emergence, and periodically for the next 5 mo. Emergent fry were examined for gross and cellular abnormalities, then cultured for 5 mo in clean water to measure delayed impacts on growth. Evaluated after exposure ended, growth was identified as an integrator of intermediateand long-term delayed response because failure to grow rapidly reduces marine survival (Parker 1971, Hargreaves \& LeBrasseur 1985). Our results are extended by responses to similar oil exposures in several previous brood years, including delayed reduction of growth and long-term marine survival (Marty et al. 1997, Heintz et al. 1999, 2000). We also measured polynuclear aromatic hydrocarbon (PAH) exposure, accumulation in tissue and composition, and determined the onset of CYP1A activity, tissue-specific induction levels and persistence after transfer to clean water.

\section{MATERIALS AND METHODS}

Collection and treatment. Pink salmon eggs were exposed to a graded dose series of weathered Alaska North Slope crude oil (5 treatments including control). To mimic realistic spill exposures, oil was artificially weathered to eliminate single-ring aromatic hydrocarbons by heating the oil at $70^{\circ} \mathrm{C}$ for $12 \mathrm{~h}$ until approximately $20 \%$ evaporated (Marty et al. 1997). Weathered oil was sprayed onto tumbling rock (mid-diameter $5.4 \mathrm{~mm}$ ) and dried 12 to $24 \mathrm{~h}$ at ambient air temperatures to model conditions in oiled intertidal substrate (e.g. Rice et al. 2001). Oil application ranged from 0 (control) to $3.8 \mathrm{~g}_{\text {oil }} \mathrm{kg}^{-1}$ rock. Rock was placed in $60 \mathrm{~cm}$ tall $\times 15 \mathrm{~cm}$ diameter polyvinyl chloride incubators $\left(27 \mathrm{~kg}\right.$ incubator $\left.{ }^{-1}\right)$, where it remained dry for an additional $13 \mathrm{~d}$. Water was passed through the rock to provide chronic, long-term embryo exposure to low TPAH concentrations. Water flow began $2 \mathrm{~d}$ prior to egg exposure to further weather the oil and remove any particulates. Flow was $1.61 \mathrm{~min}^{-1}$ and alternated between freshwater $(8 \mathrm{~h})$ and saltwater $(4 \mathrm{~h})$ to simulate an intertidal environment representative of typical pink salmon spawning habitat. Each dose was replicated in 8 incubators, except that the extreme dose was only replicated twice.

Approximately 2700 pink salmon eggs were added to each incubator about $2.6 \mathrm{~h}$ after fertilization (16 September 1999). Eggs were removed for about $1 \mathrm{~h}$ from incubators at eyeing (between Days 54 and 58) and mechanically shocked to identify and remove infertile eggs. Survival was recorded and live embryos were returned to their incubators. Alevins hatched between 25 November and 9 December; exposure continued until voluntary emergence (16 March to 18 April). Water temperature declined from $10^{\circ} \mathrm{C}$ in September to $2^{\circ} \mathrm{C}$ in late January, then increased to $4^{\circ} \mathrm{C}$ in late April.

Water and tissue samples (see Fig. 1) were collected periodically for hydrocarbon analysis. Samples were randomly composited from 3 incubators at each treatment level (3.8 $\mathrm{l}$ water and about $10 \mathrm{~g}$ tissue). Additional replicate tissue samples were collected at eyeing (Day 53) to estimate variance. Tissue and extracts from water samples were frozen pending analysis.

At emergence, fish were scored for macroscopic abnormalities (presence or absence). Potential abnormalities included external hemorrhaging, short opercular plate(s), mouth or jaw malformations, deformed caudal fin, pigmentation, bulging eyes, malformed head, pigmentation, tumors, short or malformed body, starvation, herniated yolk, damaged eyes, twinning and scoliosis. Abnormalities that correlated positively with initial aqueous TPAH concentration were summarized as total percentage of fish with abnormalities; abnormalities that correlated negatively were summarized likewise. Summary abnormalities were arcsinetransformed (Snedecor \& Cochran 1980) and analyzed with ANOVA.

For histopathologic and CYP1A analysis, tissue samples (8 to 16 treatment $^{-1}$ ) were collected on Days 27, 53 (eyeing), 76 (hatching), 146 and 201 (emergence). Additional fish were sampled weekly for 4 wk thereafter to determine organ-specific declines in CYP1A induction $(\mathrm{n}=12$ per treatment, controls and high treatment only). Samples were preserved and stepsectioned as described by Marty et al. (1997).

Tissues were immunohistochemically stained and scored blind for CYP1A expression using a standard streptavidin-biotin-HRP detection system (Olivry et al. 1997) as described by Carls et al. (2004). Staining intensity and occurrence of CYP1A were evaluated microscopically for each major tissue in each fish, and were scored on a 5-point scale: none (0), very light (1), light (2), moderate (3), or strong/widespread (4), and their product (staining score $\times$ intensity score) used for statistical analysis (Marty et al. 1997). Histopathological examination was also completed blind; samples from each replicate incubator were subdivided into 2 portions and independently assessed. Fish from the extreme treatment were not examined. The number of tissue types available for examination increased from 20 on Day 27 to 34 by Day 146; CYP1A was induced in 24 of these tissues. 
Post-emergence culturing. To evaluate delayed impacts on growth, the fish from randomly selected incubators representing each dose were cultured in clean seawater until early September 2000. From emergence in late March to late June, 22 populations of 500 fish each were cultured in $1000 \mathrm{l}$ salt water net pens (5 replicate control, low-, mid-, and high-oil populations, and 2 extreme-oil populations). Populations were randomly reduced to 250 fish in June and transferred to 701 pens. In late July, fish from each treatment were merged into single $43000 \mathrm{l}$ net pens and cultured until September. Fish were fed a commercially available diet ad libitum with automatic feeders during daylight hours. Lengths $( \pm 0.1 \mathrm{~mm}$; tip of snout to fork of tail) and whole wet weights $( \pm 1 \mathrm{mg})$ of fish were measured in late March $\left(\mathrm{n}=\sim 250\right.$ replicate $\left.^{-1}\right)$, April $(\mathrm{n}=\sim 65$ replicate $\left.^{-1}\right)$, June $\left(\mathrm{n}=\sim 110\right.$ replicate $\left.^{-1}\right)$, and September ( $\mathrm{n}=\sim 100$ treatment $\left.^{-1} ; \pm 0.1 \mathrm{~g}\right)$. Mean water temperature increased from $5.5^{\circ} \mathrm{C}$ (20 salinity) to $9.6^{\circ} \mathrm{C}$ (28 salinity) in July and declined to $9.2^{\circ} \mathrm{C}$ (28 salinity) in September.

Hydrocarbon measurement. Using the methods of Short et al. (1996), samples were extracted twice with dichloromethane after addition of 6 internal standards. Extracts were reduced in volume, exchanged with hexane over a steam bath, and fractionated and purified by alumina/silica gel chromatography. PAH were measured by gas chromatography/mass spectrometry (GC/MS) using a mass selective detector. For quality control, a method blank, spiked method blank, and 2 reference samples were analyzed with every 12 samples. Method detection limits were about $1 \mathrm{ng} \mathrm{g}^{-1}$ in tissue, and 1 to $8 \mathrm{ng} \mathrm{l}^{-1}$ in water; concentrations below method detection limits were treated as 0 . TPAH concentrations were calculated by summing concentrations of 39 individual $\mathrm{PAH}$, ranging from 2 to 5 rings (see Fig. 2 for details). Reported doses are based on initial TPAH concentrations, and are preceded by ' $<$ ' because exposure concentrations decreased exponentially.

Statistical analysis. TPAH concentrations in water and tissue were modeled to describe change over time. Change in aqueous TPAH was modeled with 2-compartment exponential decay $\left(\mathrm{TPAH}=\mathrm{ae}^{(-\mathrm{b} t)}+\mathrm{ce}^{(-\mathrm{d} t)}\right.$, where $\mathrm{a}, \mathrm{b}, \mathrm{c}$, and $\mathrm{d}$ are estimated constants and $t$ is time in days. A first-order kinetic model that accounted for TPAH uptake from water, declining aqueous TPAH concentrations, and TPAH depuration was used to predict change in TPAH concentration in tissue (Heintz et al. 1999).

Evaluation of responses through emergence: Analysis of variance (ANOVA) was applied to continuous variables, Kruskal-Wallis and Mann-Whitney $U$-tests were used to analyze ranked data, and correlation was determined by regression. Percentage data were arc- sine-transformed, and corrected for small $\mathrm{n}$ as necessary before ANOVA (Snedecor \& Cochran 1980). Treatment means were compared to control means with pairwise contrasts; the Bonferroni inequality ( $\alpha$ divided by the number of comparisons) was applied to ensure that the probability of incorrect rejection was no more than 0.05 for all comparisons. An exceptionally large residual was frequently evident in the extreme treatment; this was probably due in part to much smaller sample sizes (2 replicate incubators vs. 8 incubators in all other treatments). Where variance was heterogeneous due to the extreme treatment, ANOVAs were repeated without this group; the conclusions reached were unaltered. Histopathological data were summarized as means by incubator before further analysis to avoid pseudoreplication. For each tissue, CYP1A product scores in the high-oil treatment were compared to controls using the Mann-Whitney rank test, again applying Bonferroni inequality.

Biological responses were regressed against initial TPAH concentration; models tested were linear, exponential (log[response]), and $\log ($ concentration). Reported correlations are based on best fit models. To ensure that correlations were meaningful, we adopted the approach suggested by Draper \& Smith (1981) that the $F$-ratio of a regression $\left(F_{0}\right)$ should exceed the usual significance ratio $\left(F_{\mathrm{c}}\right)$ by a multiple of at least 4 .

The mean of CYP1A product scores was calculated for 20 responsive tissues combined to provide an overview of induction. Tissues with little or no induction were excluded. Tissues with $>3 \%$ missing data were also excluded (bulbus endothelium [heart], hepatocytes, cecal epithelium and spleen endothelium); exclusion of these 4 tissues did not change conclusions. Tissues included in summary scores were choroidal rete, gill epithelium and endothelium, pharyngeal epithelium, atrial and ventricular endothelium, vena cava, hepatocytes, bile ducts, larger veins and sinusoidal endothelium in liver, sinusoidal endothelium, tubular epithelium, renal vein endothelium in kidney, gastric epithelium, anterior and distal intestinal epithelium, yolk-sac endothelial or epithelial cells, skin epithelium, and nasal epithelial cells. Products were summed across included tissues and divided by the number present to determine summary means. These means were analyzed by Kruskal-Wallis 1-way analysis of variance on ranks with Dunn's multiple comparison test at hatch and at emergence, the 2 times when induction was measured in all treatment groups (except the extreme treatment).

Evaluation of responses after emergence: Survival in each interval between the start of culture and July was evaluated by ANOVA; exposure level was the only factor and cultured populations were the replicate observations. Survival in a given population over a 
specific interval was calculated as the number alive at the end of a sampling interval divided by the number alive at the beginning. The absence of replicate populations after July precluded the final observations (September) from analysis.

Overall survival (5.4 mo, March to September) was estimated as the product of survival over each of the sampling intervals (start of culture to April, April to June, June to July, July to September), because populations were randomly reduced in June and July. Overall survival was regressed against initial aqueous TPAH, TPAH concentration in tissue at emergence, and CYP1A induction at hatch and emergence; models tested were linear, exponential, $\log$ (concentration) and logistic.

Sizes (length and weight) of fish representing each of the treatments were compared by ANOVA and regressions. Size at emergence in April and in June was evaluated by ANOVA, with dose level as the main effect and population nested in treatments. Because populations were combined in late July, sizes in September were compared by 1-way ANOVA with oil treatment as the only factor. Sizes in each treatment were compared to controls using Dunnett's multiple comparison, with an overall $\alpha=0.05$. Weights were converted to natural logs prior to analysis, and the assumption of homogeneity of variance was tested prior to analysis using Levene's test. Lengths and weights were regressed against initial aqueous TPAH, TPAH concentration in tissue at emergence, and CYP1A induction at hatch and emergence; models tested were linear, exponential, and $\log ($ concentration).

\section{RESULTS}

\section{Hydrocarbon exposure, accumulation and loss}

Embryos and larvae were exposed to exponentially declining oil concentrations for about 200 d. Initial aqueous TPAH concentrations in treatments ranged from $0.9 \mu \mathrm{g} \mathrm{l}^{-1}$ (low treatment) to $45 \mu \mathrm{g}$ $\mathrm{l}^{-1}$ (extreme treatment) and declined exponentially with time (Fig. 1a, Table 1). By eyeing (Day 54), TPAH concentrations were 1 to $8 \%$ of initial levels and after $184 \mathrm{~d}$ (near emergence), aqueous concentrations were 0.3 to $0.7 \%$ of initial values. As a result, arithmetic and geometric mean TPAH concentrations through hatch were considerably lower than initial aqueous concentrations (Table 1). Background (control) TPAH concentration was $0.015 \pm 0.004 \mu \mathrm{g} \mathrm{l}^{-1}, \mathrm{n}=6$.
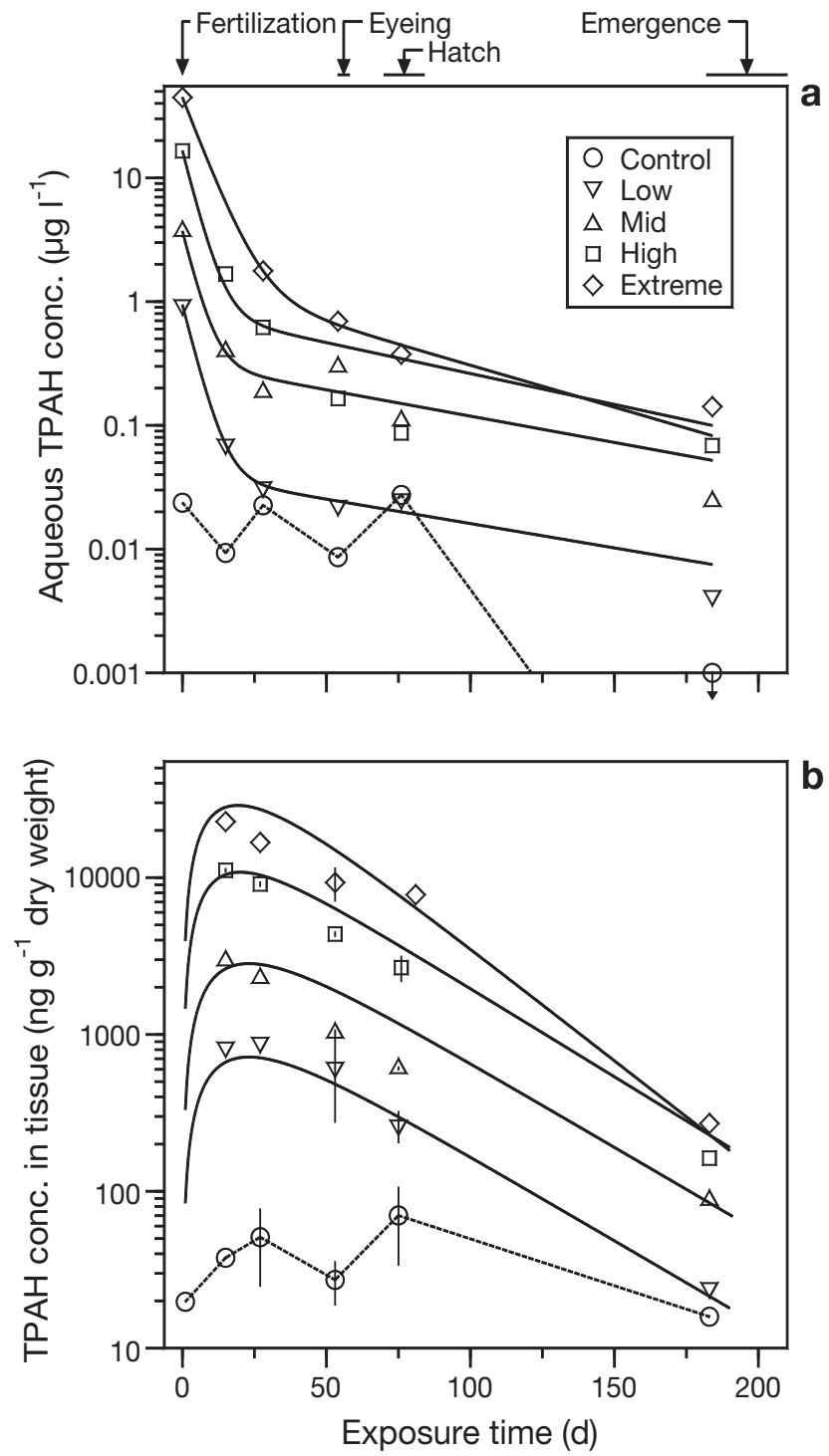

Fig. 1. Total PAH (TPAH) concentrations in (a) water and (b) egg or larval tissue, from fertilization until emergence, of Oncorhynchus gorbuscha. Aqueous models are 2-compartment exponential; tissue models are first-order kinetic that account for uptake from water and declining aqueous TPAH concentrations (Heintz et al. 1999)

Table 1. Initial and mean aqueous total PAH concentrations $\left(\mu \mathrm{g} \mathrm{l}^{-1}\right)$ for each treatment. Each water sample was a random composite of 3 incubators; thus $\mathrm{n}=1$ for each dose at each observation time. Arithmetic $( \pm \mathrm{SE})$ and geometric mean concentrations were calculated for the interval between first exposure and hatch $(n=5$, except $n=4$ in the extreme treatment)

\begin{tabular}{|lccccc|}
\hline & \multicolumn{5}{c}{ Treatment } \\
& Control & Low & Mid & High & Extreme \\
\hline Initial & 0.02 & 0.94 & 3.70 & 16.52 & 44.67 \\
Arithmetic & $0.02 \pm 0.00$ & $0.22 \pm 0.18$ & $0.94 \pm 0.69$ & $3.81 \pm 3.19$ & $11.88 \pm 10.93$ \\
Geometric & 0.02 & 0.07 & 0.39 & 0.75 & 2.13 \\
& $(0.01-0.02)$ & $(0.03-0.13)$ & $(0.21-0.71)$ & $(0.30-1.91)$ & $(0.74-6.17)$ \\
\hline
\end{tabular}


Tissues rapidly accumulated PAH (Fig. 1b). Estimated times of maximum concentration (dry weight), based on first-order kinetic modeling of all treatments, ranged from 19 to 23 d; observed maxima (influenced by sampling frequency) were on Day 15. TPAH concentrations in tissue were highly correlated with initial aqueous TPAH concentration at eyeing, hatch and emergence $\left(0.96 \leq \mathrm{r} \leq 0.98, \mathrm{p}<0.001,4 \leq F_{\mathrm{o}} / F_{\mathrm{c}} \leq 25\right)$. Bioaccumulated PAH were lost more slowly from embryo or larval tissue than $\mathrm{PAH}$ were lost from water (Carls et al. 2004).

The composition of PAH in water changed with time, consistent with normal weathering processes (Fig. 2a,b).
Naphthalenes were initially dominant, followed by phenanthrenes, then fluorenes and dibenzothiophenes. By Day 54, phenanthrenes were either dominant or approached dominance. Within homologous families, unsubstituted compounds were lost first. Increasingly substituted compounds were typically retained progressively better in the upper 2 doses.

The composition of PAH in tissue became increasingly naphthalene-dominated, a trend opposite to that in water, possibly because phenanthrenes and larger $\mathrm{PAH}$ were metabolized more rapidly than smaller PAH such as naphthalenes (Fig. 2c,d). Phenanthrenes were the secondmost abundant group (typically 10 to $21 \%$ ), and chrysenes were the least represented $(\leq 0.7 \%)$. Relative phenanthrene concentrations in tissue consistently decreased throughout exposure, despite relative increases in water, suggesting active removal by metabolic action.

\section{Short-term biological response}

Embryo survival was reduced by exposure to oil (Fig. 3a). Survival at emergence was significantly depressed $(6$ to $35 \%$ ) in the upper 2 treatments, and the lowest observed effective concentration (LOEC) was $<16.5 \mu \mathrm{g}^{-1}\left(0.001<\mathrm{p}_{\text {ANOVA }} \leq\right.$ 0.006). Earlier survival (at eyeing) trended downward as dose increased, but was not significantly reduced $\left(\mathrm{r}^{2}=0.15\right.$, $\left.\mathrm{p}=0.010, F_{\mathrm{o}} / F_{\mathrm{C}}=1.8, \mathrm{p}_{\mathrm{ANOVA}}=0.240\right)$.

Some macroscopic abnormalities were positively correlated with TPAH exposure (Fig. 3b); others were negatively correlated or uncorrelated. Abnormalities that were positively correlated with exposure $(\mathrm{p} \leq 0.003)$ were ascites $(\mathrm{r}=$ 0.88), bulging eyes (0.88), malformed head (0.73), short opercular plates (0.66), external hemorrhaging (0.70), mouth or jaw malformations (0.63), and deformed caudal fin (0.49). In all cases except caudal fin deformation, $F_{\mathrm{o}} / F_{\mathrm{C}} \geq 5$-strong support for a significant relationship. Unusual pigmentation $(\mathrm{r}=-0.58)$ and tumors (0.36) were negatively correlated with exposure $\left(1 \leq F_{\mathrm{o}} / F_{\mathrm{c}} \leq 4\right.$, $0.001 \leq \mathrm{p} \leq 0.037$ ), probably because embryos with these developmental problems were less likely to survive oil exposure. No other abnormalities were significantly correlated with oil exposure $(-0.32 \leq \mathrm{r} \leq 0.11,0.064 \leq \mathrm{p} \leq 0.920$,
Fig. 2. Example PAH composition in (a,b) high-oil treatment water and (c,d) egg tissue of Oncorhynchus gorbuscha. Percentages inside graphs are total percentages (from left to right) of the following homologous groups: naphthalene (Naph), fluorenes (Fluor), dibenzothiophenes (Dibenz), phenanthrenes (Phenan), and chrysenes; PAH heavier than chrysenes were present in the oil, but were not detected in water or tissue-benzo(b)fluoranthene, benzo(k)fluoranthene, benzo(e)pyrene, benzo(a)pyrene, perylene, indeno(1,2,3-cd)pyrene, benzo(a,h)anthracene, and benzo(ghi)perylene. Weathering in water was evident as composition shifted from naphthalene dominance toward phenanthrene dominance 

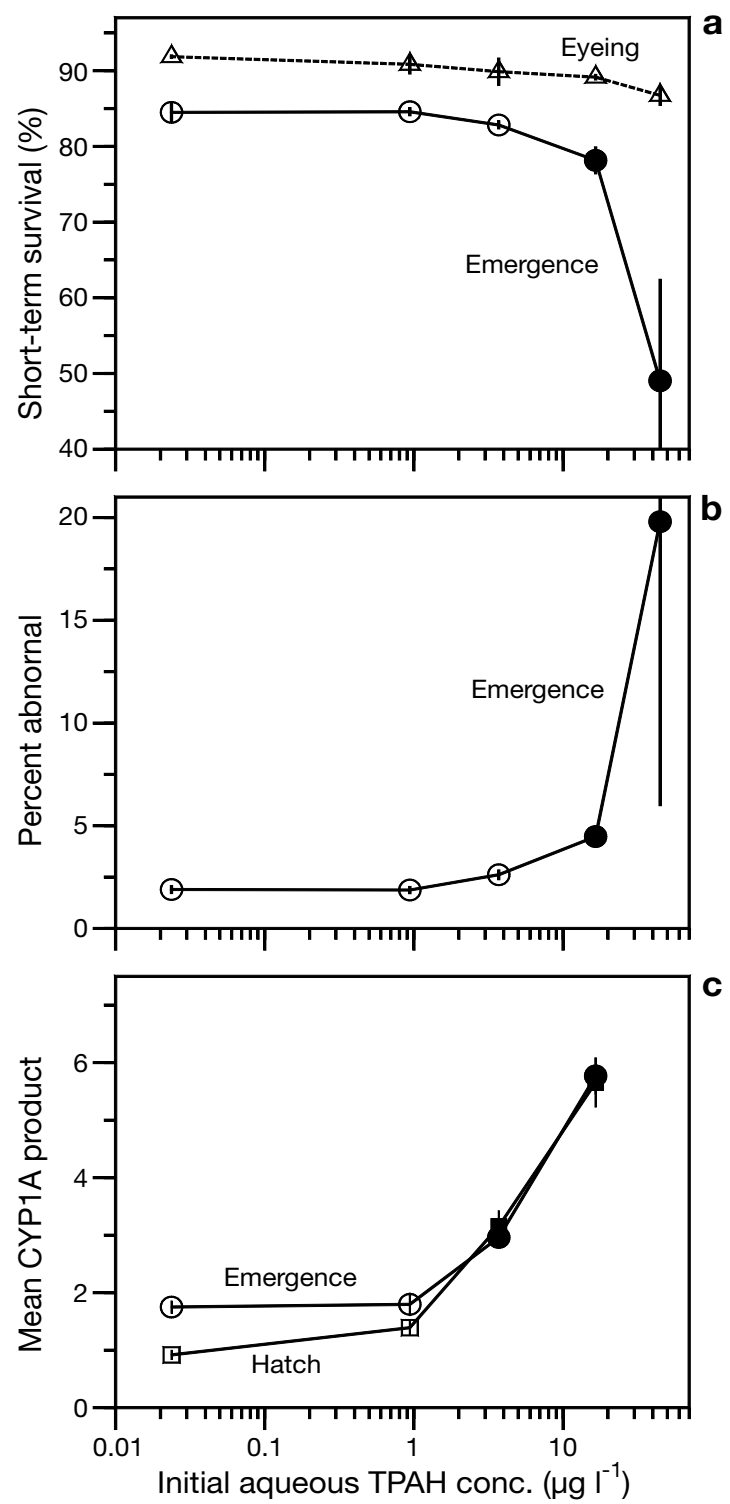

Fig. 3. Oncorhynchus gorbuscha. (a) Mean $( \pm \mathrm{SE})$ short-term larval survival, (b) incidence of macroscopic abnormalities, and (c) cytochrome P4501A (CYP1A) induction (staining score $\times$ intensity score) related to initial TPAH concentration in water. Observation times are indicated for each data set (eyeing, hatch or emergence). Abnormalities summarized in (b) are those whose incidence increased with increasing oil exposure (see 'Results'). Mean CYP1A product summarizes 20 of 24 inducible tissues; 4 inducible tissues that were sampled $<97 \%$ of the time were not included. Filled symbols indicate significant differences from control response

$\left.0.0 \leq F_{\mathrm{o}} / F_{\mathrm{C}} \leq 0.9\right)$, but the incidence of body malformation, herniated yolk and twinning fell to zero in the extreme dose, suggesting a possible negative relationship at high oil concentrations $\left(<45 \mu g \mathrm{l}^{-1} \mathrm{TPAH}\right)$. The combined incidence of all positively correlated macroscopic abnormalities was significantly elevated in the upper 2 treatments $\left(\mathrm{LOEC}<16.5 \mathrm{\mu g} \mathrm{l}^{-1} ; 0.001<\mathrm{p}_{\mathrm{ANOVA}}\right.$ $\leq 0.011$; Fig. 3b) and was correlated with CYP1A induction $(\mathrm{r}=0.78)$. The combined incidence of negatively correlated abnormalities was depressed in these treatments $\left(0.001<\mathrm{p}_{\mathrm{ANOVA}} \leq 0.013\right)$.

Some histological changes were positively correlated with $\mathrm{TPAH}_{i}$ others were negatively correlated or uncorrelated. Extreme-treatment tissues were not examined. Positively correlated with TPAH concentration were proteinaceous ascites $(r=0.52)$, hepatocellular necrosis (0.46), epidermal cell apoptosis (0.43), peritonitis $(0.43)$, and gastric epithelial apoptosis $(0.37)\left(1 \leq F_{0} / F_{\mathrm{c}} \leq 3\right)$. Proteinaceous ascites was significantly elevated in the high-oil treatment $\left(p_{\text {Kruskal-Wallis }}=0.047\right)$ (Fig. 4). Negative
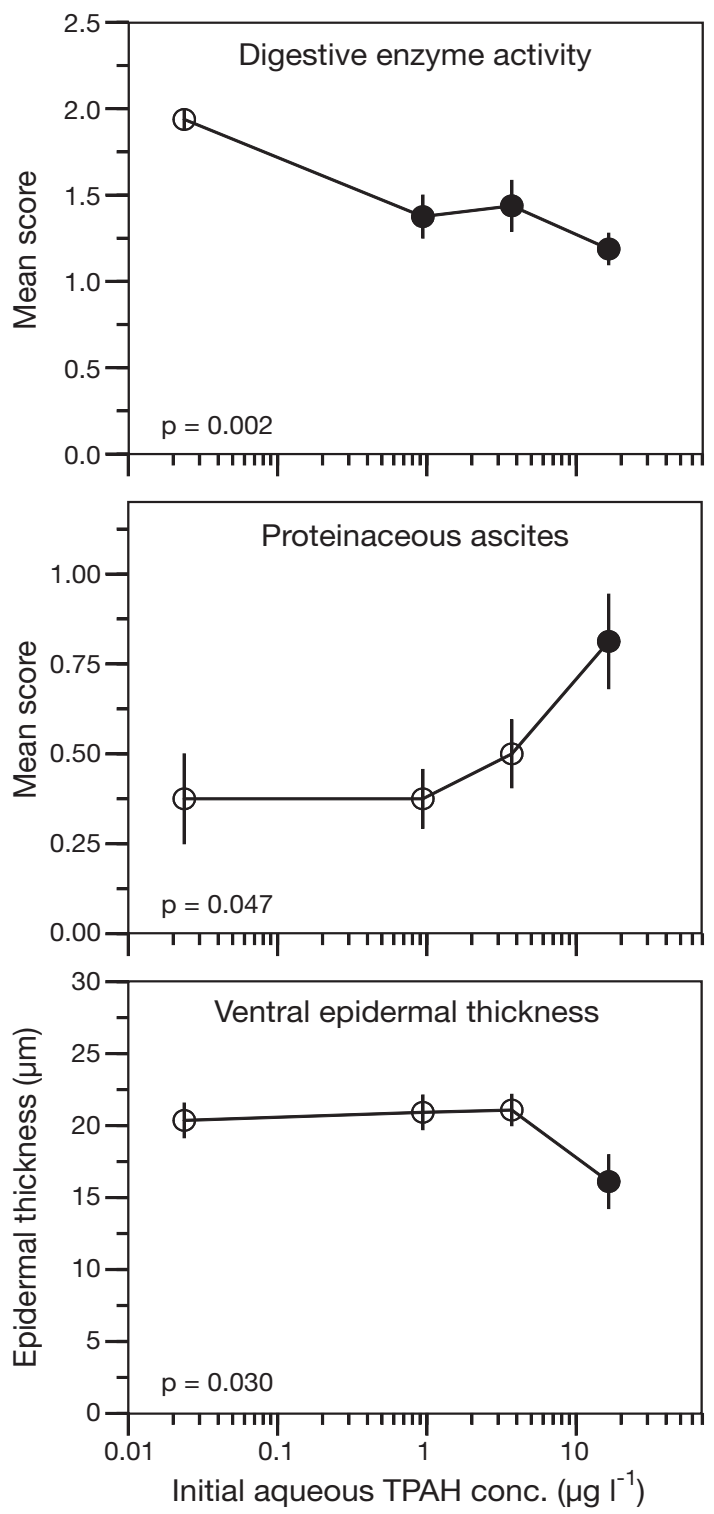

Fig. 4. Oncorhynchus gorbuscha. Example of mean $( \pm \mathrm{SE})$ histological changes in emergent fry (of 20 responses monitored) related to initial TPAH concentration in water. Filled symbols indicate significant differences from control response 
correlates were digestive enzyme activity $(\mathrm{r}=-0.66$, $\left.F_{\mathrm{o}} / F_{\mathrm{C}}=5\right)$, relative volume of adipose tissue ( $\mathrm{r}=-0.59$, $\left.F_{\mathrm{o}} / F_{\mathrm{C}}=4\right)$, and epidermal thickness $(-0.51 \leq \mathrm{r} \leq-0.41,1 \leq$ $F_{\mathrm{o}} / F_{\mathrm{C}} \leq 3$ ). (Digestive enzyme activity was inferred from autolysis, primarily the tips of intestinal villi and tissues around bile ducts.) Ventral epidermal thickness was significantly depressed in the high-oil treatment (TPAH < $16.5 \mu \mathrm{g} \mathrm{l}^{-1}, \mathrm{p}_{\text {Kruskal-Wallis }}=0.030$ ) and digestive enzyme activity was significantly depressed in all oil treatments $\left(\mathrm{TPAH}<0.94 \mu \mathrm{g} \mathrm{l}^{-1}, \mathrm{p}_{\text {Kruskal-Wallis }}=0.002\right)$ (Fig. 4). All identified histological changes were also correlated with CYP1A induction, with r values about the same as those for TPAH.

\section{CYP1A induction patterns}

CYP1A was induced by exposure to oil starting early in embryonic development, and typically remained at elevated levels until after emergence (Fig. 5). Mean induction in larvae at hatch and emergence was correlated with initial aqueous TPAH concentration $(0.85 \leq$ $\left.\mathrm{r} \leq 0.89, \mathrm{p}<0.001,39 \leq F_{\mathrm{o}} / F_{\mathrm{c}} \leq 58\right)$; the LOEC was $<3.7 \mathrm{\mu g} \mathrm{l}^{-1}$ (Fig. 3c).

There were dramatic differences in CYP1A induction among tissues between hatch and emergence, despite the similarity of average responses summa- rized in Fig. 3c. A variety of CYP1A induction patterns were evident, including an early peak (Days 27 to 53) in 9 of 34 tissues examined, maxima about midway through exposure (Days 76 to 146) in 7 tissues, maxima at the end of exposure (Day 201) in 3 tissues, and variable or nearly constant induction in 5 tissues (Fig. 6). Little or no induction was evident in the remaining 10 of 34 tissues (eye lens, maxillary, periocular, pectoral and vertebral perichondrial cells, pseudobranch vessels and glandular cells, archinephric duct epithelium, pancreatic acinar cells and gonads).

The frequency of significant CYP1A induction increased from the time embryos were first observed until hatch, and remained high until oil exposure ended at emergence. On Day 27, shortly after the estimated onset of eye pigmentation (Smirnov 1975), induction was significant in 4 of 15 inducible tissues. By hatch, CYP1A induction was significant in 14 of 23 inducible tissues and was significantly correlated with
Fig. 5. Oncorhynchus gorbuscha. A $53 \mathrm{~d}$ old embryo exposed to weathered crude oil since fertilization. Immunohistochemical stain for cytochrome P4501A is red; hematoxylin (light blue) is counterstain; box indicates that part of kidney shown at high magnification in larger inset. CYP1A is prominent in yolk sac (y), skin (external surface), and in endothelial cells (arrowheads) of large blood vessels (v) and small sinusoids of kidney. Staining is less intense in kidney tubules (t), and blood vessels of the gill $(\mathrm{g})$ and brain (b). Also labeled are retina $(\mathrm{r})$, otolith chamber (o), pectoral fin (f), and skeletal muscle (s). Control kidney is shown for reference in smaller inset

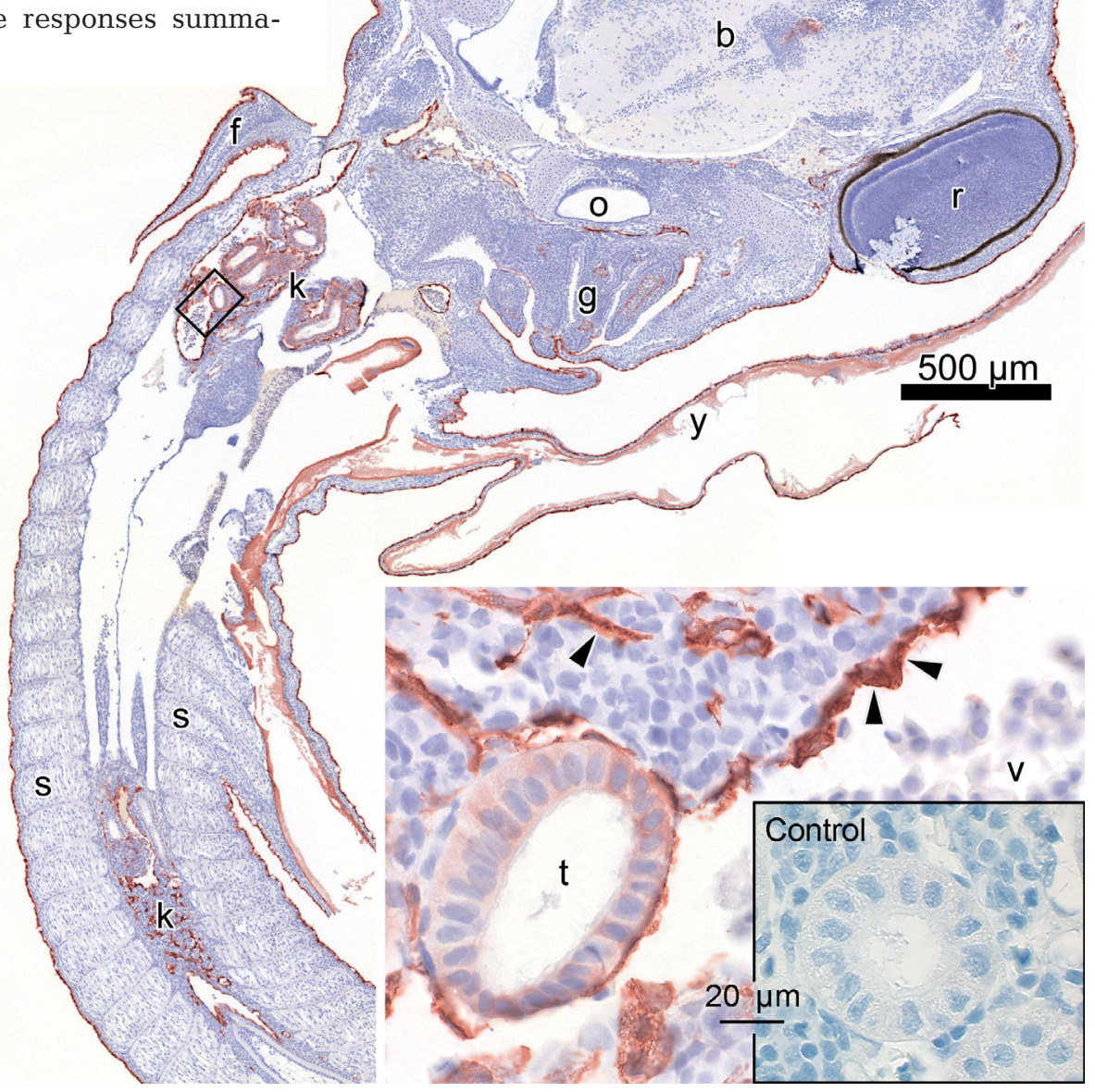



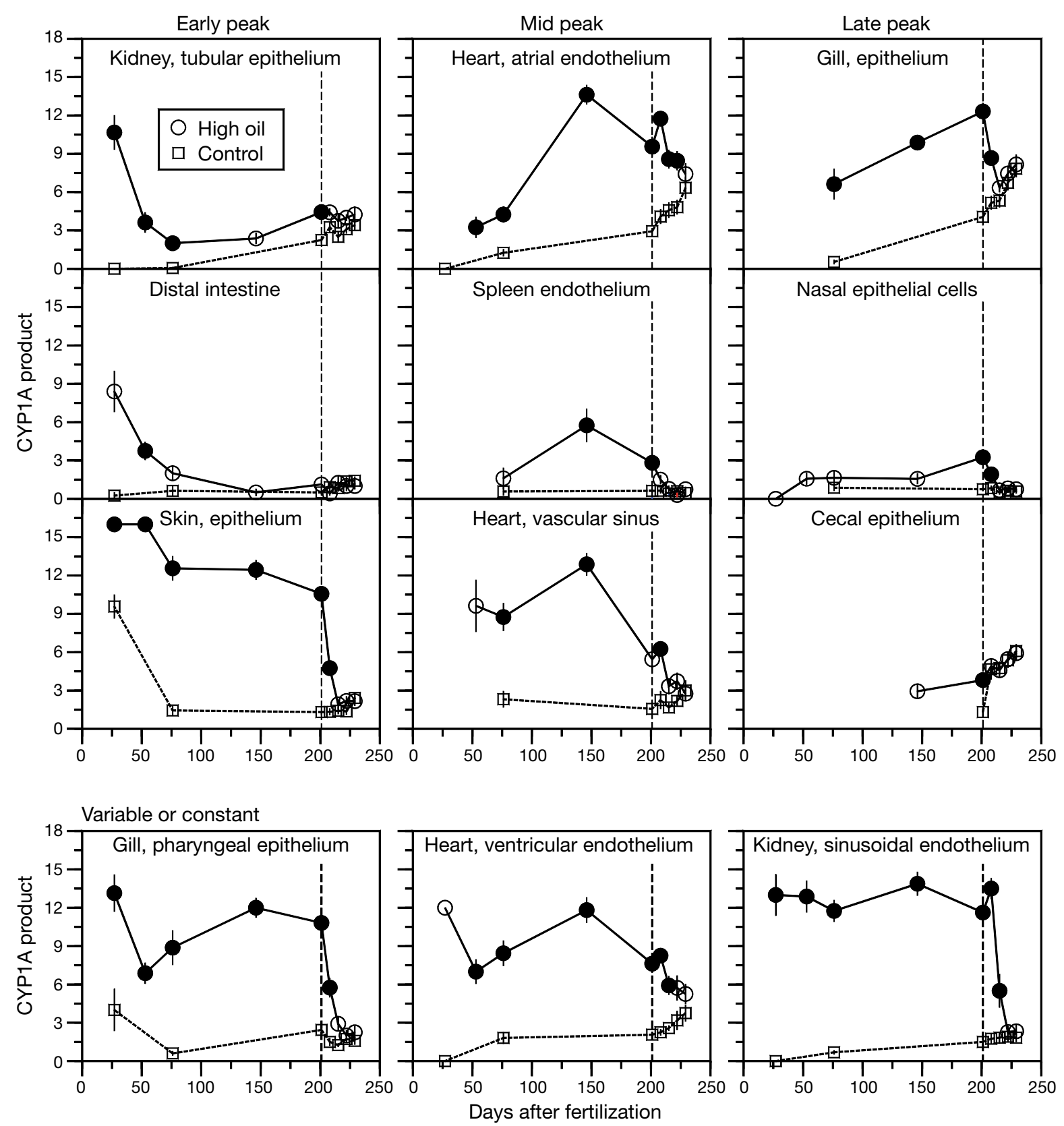

Fig. 6. Oncorhynchus gorbuscha. Mean $( \pm$ SE) cytochrome P4501A (CYP1A) induction product (staining score $\times$ intensity score) in representative inducible tissues over time. Other tissues in which CYP1A induction peaked early were glomerular and renal vein endothelium in kidney; gastric epithelium, anterior intestine, endothelial or epithelial cells in yolk sac; and hepatocytes. Induction that peaked midway through incubation also included bile ducts, heart bulbus endothelium and sinusoidal endothelium and larger veins in liver. All 3 tissues with late induction are illustrated. Additional tissues in which CYP1A induction was variable or roughly constant through incubation included choroidal rete and gill arch/filament endothelium. Black symbols indicate significant differences from controls (Mann-Whitney $U$-test). Vertical dashed lines indicate time of transfer to clean water

TPAH in all $14\left(0.46 \leq \mathrm{r} \leq 0.88, \mathrm{p}<0.001,4 \leq F_{\mathrm{o}} / F_{\mathrm{C}} \leq 52\right)$. At emergence, CYP1A induction was significant in 16 of 24 tissues and was significantly correlated with TPAH in 17 tissues $\left(0.50 \leq \mathrm{r} \leq 0.94, \mathrm{p}<0.001,5 \leq F_{0} / F_{\mathrm{c}}\right.$ $\leq 123)$. The LOEC causing CYP1A induction in individual tissues was $<3.7 \mu \mathrm{g} \mathrm{l}^{-1}$ at hatch and at emergence.
Before emergence, control CYP1A was $<2.5$ in $89 \%$ of all observations (inducible tissues only); 3 general control patterns were apparent over time: (1) low level (CYP1A <1) with no general trend (6 tissues), (2) a general increase toward emergence (13 tissues), and (3) generally declining induction toward emergence 
(4 tissues) (Fig. 6). Control induction in the last group was unusual and outlying in 3 cases; on Day 27, mean induction was 4.0 in pharyngeal epithelium, 3.6 in yolk-sac endothelial or epithelial cells, and 9.6 in skin epithelium, an extreme control outlier. Corresponding induction in oil-treated fish exceeded these unusual control responses by 6.4 to 9.5 units. Control induction was not unusual in any of the outlier tissues in subsequent observations. CYP1A induction physiology in the first few weeks of embryo development merits further attention.

After emergence, CYP1A induction in controls increased abruptly in about half of all inducible control tissues (Fig. 6). While these changes in baseline did not obscure dose-induced relationships, they clearly indicate that unknown endogenous or exogenous inducers were present after emergence. Increased induction in controls underscores the need for suitable reference alevins in field studies.

CYP1A induction in high-treatment fish merged with control induction after emergence (and transfer to clean water), a process that ranged from $<1 \mathrm{wk}$ to $>3$ wk (e.g. Fig. 6). Of the 16 tissues with significantly elevated CYP1A at emergence, 5 returned to baseline within 1 wk (bulbous endothelium, tubular epithelium [kidney], cecal epithelium, anterior intestinal epithelium, and spleen endothelium), 7 within 2 wk (gill epithelium and endothelium, pharyngeal epithelium, sinusoidal endothelium [liver], larger liver veins, skin epithelium and nasal epithelial cells), 3 within $3 \mathrm{wk}$ (ventricular endothelium, sinusoidal endothelium [kidney] and renal vein endothelium), and 1 within 4 wk (atrial endothelium).

\section{Post-exposure survival, size and growth}

Delayed oil impact on survival was clear by September, 5 mo after exposure ended, but not after 3 mo. Reduced survival of fish exposed as embryos and cultured in clean water from March to September was correlated with initial aqueous TPAH $(\mathrm{r}=-0.83$, $\left.F_{\mathrm{o}} / F_{\mathrm{C}}=9.7\right)$, TPAH in tissue at emergence $(\mathrm{r}=-0.74$, $\left.F_{\mathrm{o}} / F_{\mathrm{C}}=5.2\right)$, and CYP1A induction at hatch and emergence $\left(-0.82 \leq \mathrm{r} \leq-0.72,4.7 \leq F_{0} / F_{\mathrm{C}} \leq 9.0\right)$. By September, post-exposure survival was significantly less in the extreme oil treatment (TPAH $<44.7 \mu \mathrm{g} \mathrm{l}^{-1}$ ) than in controls (Fig. 7) and these fish consistently had the lowest average survival rates in each observation interval.

Fish from all oil treatments grew less than controls, and this was more evident 5 mo after exposure than after 3 mo (Fig. 7). High-treatment fish were significantly shorter than controls at all times; mid-treatment fish were significantly shorter at emergence and in September. Extreme-treatment fish were also sig- nificantly shorter at emergence but did not follow expected patterns in June, and September, probably the consequence of natural selection: survival of only the most robust extreme-treatment fish (Fig. 3a), was evident by June and more pronounced in September as weaker fish in this treatment continued to die (Fig. 7). Differences in mean length among treated fish and controls were small at emergence $(0.2$ to $1.4 \mathrm{~mm})$ and increased with time (1.8 to $6.9 \mathrm{~mm}$ in September). Excluding the extreme-treatment response, reduced fish length in September was related to initial aqueous TPAH concentration, TPAH concentration in tissue at emergence, and CYP1A induction at hatch and emergence $\left(p_{\text {regression }} \leq 0.001,6.2 \leq F_{\mathrm{o}} / F_{\mathrm{c}} \leq 9.1\right)$, but correlation was consistently poor because length varied widely within each treatment $(-0.28 \leq r \leq 0.23)$. Similar dose-dependent length declines were evident at each earlier observation time. The LOEC for reduced length was $<3.7 \mu \mathrm{g} \mathrm{l}^{-1}$ aqueous TPAH in September, $5 \mathrm{mo}$ after exposure ended.

Fish mass also declined in a dose-dependent fashion (Fig. 7). Weight at emergence was significantly depressed only in the extreme treatment. As with lengths, differences among treated fish and controls increased with time, and in September, weights in low-, mid- and high-oil treatments decreased systematically with exposure level and were significantly less than in controls $\left(\mathrm{p}_{\text {ANOVA }}<0.001\right)$. Because only the most robust extreme-treatment fish apparently survived, mass in this treatment did not follow general trends by June. Excluding the extreme-treatment response, reduced fish mass in September was related to initial aqueous TPAH concentration, TPAH concentration in tissue at emergence, and CYP1A induction at hatch and emergence ( $\mathrm{p}_{\text {regression }} \leq 0.001,2.8 \leq F_{\mathrm{o}} / F_{\mathrm{c}} \leq$ 6.2 ), but correlation was consistently poor because wet weight varied widely within each treatment $(-0.23 \leq$ $\mathrm{r} \leq 0.16)$. The LOEC for reduced mass was $<0.94 \mu \mathrm{g} \mathrm{l}^{-1}$ aqueous TPAH in September.

\section{DISCUSSION}

Induction of CYP1A indicates exposure of vertebrates to petroleum and other planar hydrocarbons, but the physiological importance of this response is sometimes questioned. While CYP1A induction indicates exposure to and metabolism of aromatic hydrocarbons, does it indicate damage and decreased potential for long-term survival? In our experiments with pink salmon embryos, CYP1A induction indicates that long-term damage is probable, leading to reduced survival.

Short-term and intermediate-term physiological responses were evident during exposure and in the months after exposure ended. Abnormalities were 

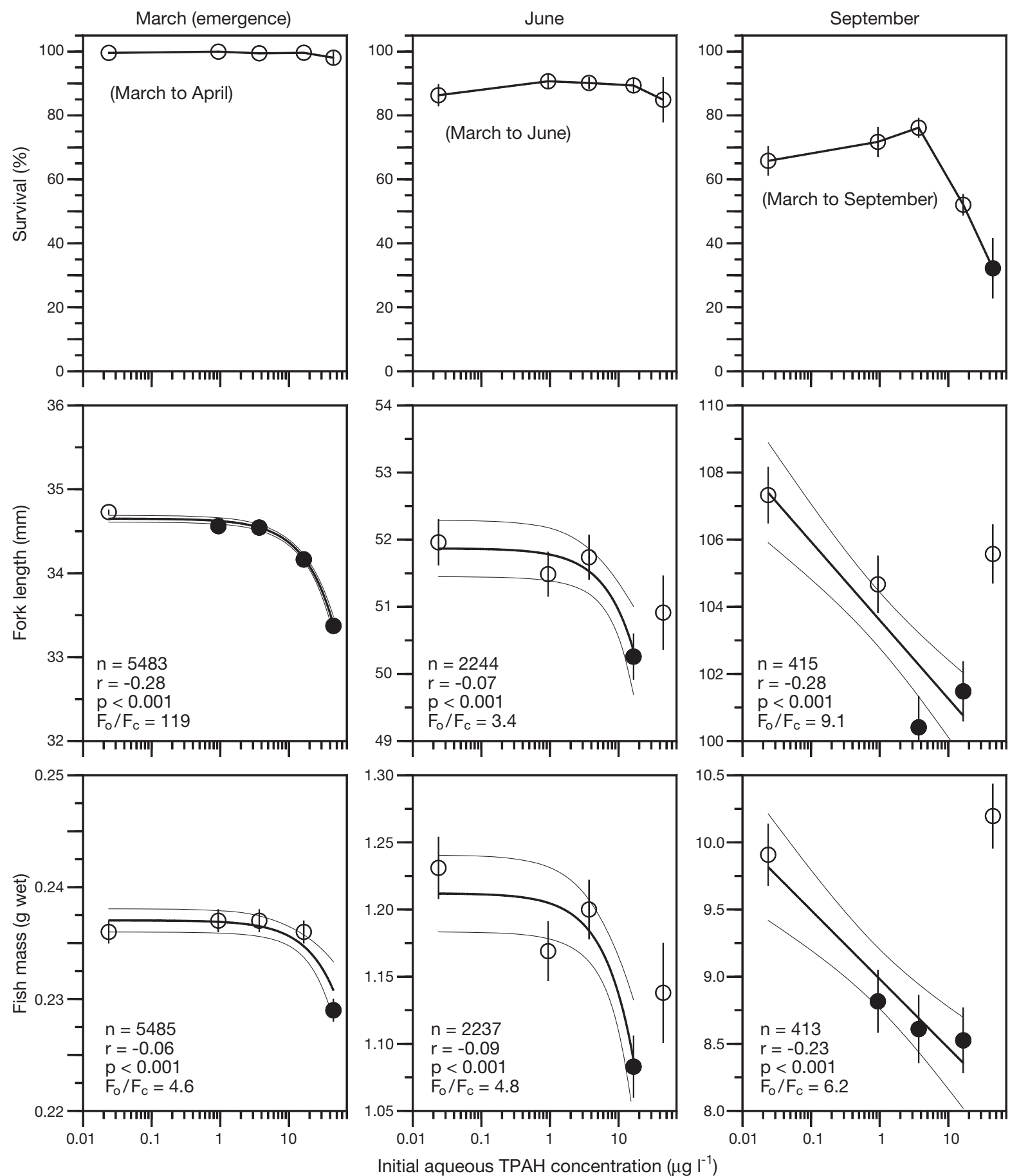

Fig. 7. Oncorhynchus gorbuscha. Mean $( \pm$ SE) fish survival, length and weight in March (emergence), June (2.5 mo after emergence and transfer to clean water), and September (5.4 mo after) related to initial TPAH concentration in water. Black symbols indicate significant differences from control response. Length and weight in extreme-oil treatment $\left(<45 \mu \mathrm{g} \mathrm{l^{-1 } )}\right.$ were probably biased upward by selective mortality; thus, this treatment was not included in the June and September regressions

caused by 6 mo exposure to exponentially declining aqueous TPAH concentrations, and size differences became more pronounced in the months after emergence to clean water. Embryonic response to accumulated hydrocarbons is quick; CYP1A induction was observed in developing tissues at the first sampling. Importantly, concentrations that induced CYP1A were similar to those causing adverse physiological effects (the LOECs were $<3.7$ and $<0.94 \mu \mathrm{g} \mathrm{l}^{-1} \mathrm{TPAH}$, respectively). Thus, not only is CYP1A a sensitive measure 
of hydrocarbon exposure, it clearly correlates with adverse short- to intermediate-term effects in exposed embryos.

Most importantly, however, CYP1A response in embryos implies that reduced long-term survival is likely. In similar exposures to $\mathrm{PAH}$ with pink salmon embryos, earlier studies found both short- and longterm effects, including poor adult returns when embryos were exposed to similar dose levels (Marty et al. 1997, Heintz et al. 1999, 2000). Specifically, depressed fry growth and significantly reduced marine survival were observed after exposure of pink salmon embryos to $<5.2 \mu \mathrm{g} \mathrm{l}^{-1}$ aqueous TPAH concentrations (Heintz et al. 2000). Induction of CYP1A was not examined in the experiment of Heintz et al. (2000), but current results clearly demonstrate that induction must also have occurred in those earlier brood years (1993, 1995 and 1998). Embryo exposures in previous experiments were to the same oil and administered in the same manner; apparently healthy emergent fry were tagged and released into the marine environment and dose effects were evaluated $1.5 \mathrm{yr}$ later in returning adults. These tests confirm that long-term consequences can be expected from low exposure doses to embryos. Consistent with the hypothesis that CYP1A was induced in all brood years was the observation of induction in oil-exposed embryos from the 1992 brood year (Marty et al. 1997). Thus, the meta-experiment, which includes embryos exposed in 1992, 1993, 1995, 1998 and 1999, demonstrates that CYP1A induction in embryos is linked to reduced marine survival, and ergo population-level effects.

Reduced growth potential in the marine environment, caused by toxic action in oil-exposed embryos, is probably the key functional change that leads to the distinct survival disadvantage and fewer returning adult spawners. Rapid fry growth after emigration to the marine environment is important to escape mortality from size-selective predation (Parker 1971, Healey 1982, Hargreaves \& LeBrasseur 1985), thus placing oilexposed fish at a disadvantage. In the oil-exposure tests with pink salmon embryos followed by released fry, reduced marine survival of pink salmon adults has been directly observed in 3 different brood years (1993, 1995 and 1998; Heintz et al. 2000). Exposure methods in each year were the same as those employed in the present experiment, and the LOEC for reduced marine survival was $<5.2 \mu \mathrm{g}^{-1}$ (Heintz et al. 2000). Depressed marine survival was consistently correlated with depressed growth rate 4 to 10 mo after emergence, and was a more sensitive measure of significant response in 1995 fish than growth rate. Consequently, CYP1A in the embryos predicts short-term effects, long-term growth depression, and ultimately a negative effect on adult recruitment.
The model of activity demonstrated here is consistent with a similar cascade of effects described in Prince William Sound after the 'Exxon Valdez' oil spill. In juvenile pink salmon in marine water, CYP1A was induced by oil, and growth slowed (Carls et al. 1996, Wertheimer \& Celewycz 1996, Willette 1996). Geiger et al. (1996) estimated that approximately 1.9 million wild pink salmon failed to return as adults in 1990 because poor growth reduced survival (about 28\% of the potential wild-stock production in the SW portion of Prince William Sound). Pink salmon embryos incubating in the intertidal reaches of streams were exposed to PAH from oil-coated intertidal sediment; CYP1A was induced and survival was significantly reduced through 1993 (Bue et al. 1996, 1998, Wiedmer et al. 1996, Craig et al. 2002, Carls et al. 2003). Gieger et al. (1996) estimated that 60000 to 70000 pink salmon failed to return as adults in 1991 and 1992, respectively, as a result of toxic exposure. Thus, the CYP1A induction and responses we report are consistent with these field data.

Induction of CYP1A throughout development is evidence for the vulnerability of embryos to PAH. Induction at the earliest observation (Day 27) demonstrates that PAHs had perfused into tissues of exposed embryos. Tissues where CYP1A was not induced had either not developed catabolic capabilities or were not exposed. Our observation of decreasing CYP1A activity with increasing embryo age in some tissues cannot be separated from declining PAH exposure, although possibly some tissues may have been protected by the metabolic action of adjacent tissue. For example, the increased capacity of the endothelium of large vessels in the liver to metabolize PAH may have reduced exposure of hepatocytes and bile ducts. In contrast, induction remained high or increased with time in certain other tissues (Fig. 6).

Exposure to PAH during the earliest stages of development may significantly increase the risk of damage to developing embryos, consistent with the general observation that early life stages are highly vulnerable to pollutants (e.g. Moore \& Dwyer 1974). One hypothesis suggests that because the proportion of undifferentiated cells among all cells is largest early in development, damage will lead to a wide variety of potential effects in the resulting daughter cells, leading to the immediate, secondary, and delayed effects described herein. Another possibility is that damage to critical organs causes secondary damage to other tissues. For example, cardiac conduction was impeded by exposure of zebrafish Danio rerio embryos exposed to dibenzothiophenes and phenanthrenes, resulting in secondary effects on cardiac morphogenesis, kidney development, neural tube structure and formation of the craniofacial skeleton (Incardona et al. 2004). The 
relative importance of primary and secondary effects on embryo development remains open to further study. Changing metabolic profiles as various enzymes are activated or repressed may also influence embryonic sensitivity during development (Miller et al. 1996). Permanent, multiple defects are likely to have lasting consequences, such as poorer growth and marine survival (e.g. Heintz et al. 2000).

We expect that our observations may be generalized to all fish; CYP1A induction has been observed in many species and in many of the same tissues (e.g. Sarasquete \& Segner 2000, Stegeman et al. 2001). Immunohistochemical measurement of CYP1A, as completed in this study, is consistent with other detection methods, including immunoblotting and catalytic activity (e.g. 7-ethoxyresorufin-O-deethylase) (Woodin et al. 1997, Stagg et al. 2000, Hyyti et al. 2001). Tissues identified with moderate to strong induction throughout the observation period (gill, heart, kidney, liver, gastrointestinal tract, yolk sac and skin) have been commonly induced in pink salmon tissue in other laboratory and field studies, illustrating their usefulness for continued study (Carls et al. 1996, 2004, Wiedmer et al. 1996). However, cell-specific induction may vary with inducer type and dose, species, and exposure route (Sarasquete \& Segner 2000); hence we recommend examination of all major organs.

We conclude that induction of CYP1A is statistically correlated with adverse effects at cellular, organism and population levels in pink salmon and can be used to predict these responses. Exposure of pink salmon embryos and larvae to oil caused a variety of lethal and sublethal effects. The LOECs causing CYP1A induction during embryonic development and reduced fish length 6 mo after exposure ended were equal $(<3.7 \mu \mathrm{g}$ $\left.\mathrm{l}^{-1}\right)$; mass reduction was even more sensitive to exposure $\left(<0.94 \mu \mathrm{g} \mathrm{l}^{-1}\right)$. By emergence, fish survival in treatments $>3.7 \mathrm{\mu g} \mathrm{l}^{-1}$ was reduced, and treated fish continued to die during the next 6 mo. The combined results from a series of embryo-larval exposure experiments spanning 5 brood years are consistent, and demonstrate that CYP1A induction is related to a variety of lethal and sublethal effects, including abnormalities, reduced growth and diminished marine survival. Thus, CYP1A induction can be considered a bioindicator; observation of induction in early life stages implies long-term negative consequences for the individual and the population at similar exposure levels.

Acknowledgements. We thank R. Bradshaw for laboratory support, J. Lunasin, M. Larsen, and L. Holland for hydrocarbon measurement, and the 'Exxon Valdez' Oil Spill Trustee Council for support of this research. The findings and conclusions presented by the authors are their own and do not necessarily reflect the view or position of the Trustee Council.

\section{LITERATURE CITED}

Barron MG, Carls MG, Short JW, Rice SD (2003) Photoenhanced toxicity of aqueous phase and chemicallydispersed weathered Alaska North Slope crude oil to Pacific herring eggs and larvae. Environ Toxicol Chem 22:650-660

Bue BG, Sharr S, Moffitt SD, Craig A (1996) Effects of the Exxon Valdez oil spill on pink salmon embryos and preemergent fry. Am Fish Soc Symp 18:619-627

Bue BG, Sharr S, Seeb JE (1998) Evidence of damage to pink salmon populations inhabiting Prince William Sound, Alaska, 2 generations after the Exxon Valdez oil spill. Trans Am Fish Soc 127:35-43

Carls MG, Wertheimer AC, Short JW, Smolowitz RM, Stegeman JJ (1996) Contamination of juvenile pink and chum salmon by hydrocarbons in Prince William Sound after the Exxon Valdez oil spill. Am Fish Soc Symp 18:593-607

Carls MG, Rice SD, Hose JE (1999) Sensitivity of fish embryos to weathered crude oil. Part 1. Low level exposure during incubation causes malformations and genetic damage in larval Pacific herring (Clupea pallasi). Environ Toxicol Chem 18:481-493

Carls MG, Thomas RE, Rice SD (2003) Mechanism for transport of oil-contaminated water into pink salmon redds. Mar Ecol Prog Ser 248:245-255

Carls MG, Holland L, Short JW, Heintz RA, Rice SD (2004) Monitoring polynuclear aromatic hydrocarbons in aqueous environments with passive low-density polyethylene membrane devices. Environ Toxicol Chem 23:1416-1424

Craig AK, Willette M, Evans DG, Bue BG (2002) Injury to pink salmon embryos in Prince William Sound-field monitoring. Restoration Report 98191A-1 Exxon Valdez Oil Spill Final Report. Alaska Department of Fish and Game, Anchorage, AK

Draper NR, Smith H (1981) Applied regression analysis, 2nd edn. John Wiley \& Sons, New York

Geiger HJ, Bue BG, Sharr S, Wertheimer AC, Willette TM (1996) A life history approach to estimating damage to Prince William Sound pink salmon caused by the Exxon Valdez oil spill. Am Fish Soc Symp 18:487-498

Hargreaves NB, LeBrasseur RJ (1985) Species selective predation on juvenile pink (Oncorhynchus gorbuscha) and chum (O. keta) by coho salmon (O. kisutch). Can J Fish Aquat Sci 42:659-668

Healey MC (1982) Timing and relative intensity of sizeselective mortality of juvenile chum salmon during early sea life. Can J Fish Aquat Sci 39:952-957

Heintz R, Short JW, Rice SD (1999) Sensitivity of fish embryos to weathered crude oil. Part II. Increased mortality of pink salmon (Oncorhynchus gorbuscha) embryos incubating downstream from weathered Exxon Valdez crude oil. Environ Toxicol Chem 18:494-503

Heintz RA, Rice SD, Wertheimer AC, Bradshaw RF, Thrower FP, Joyce JE, Short JW (2000) Delayed effects on growth and marine survival of pink salmon Oncorhynchus gorbuscha after exposure to crude oil during embryonic development. Mar Ecol Prog Ser 208:205-216

Hodson PV, Cross T, Ewert A, Zambon S, Lee K (2002) Evidence for the bioavailability of PAH from oiled beach sediments in situ. In: Proc 25th Arctic and Marine Oilspill Program (AMOP) technical seminar. Environment Canada, Calgary, p 379-388

Hyyti OM, Nyman M, Willis ML, Raunio H, Pelkonen O (2001) Distribution of cytochrome P4501A (CYP1A) in the tissues of Baltic ringed and grey seals. Mar Environ Res 51: 465-485 
Incardona JP, Collier TK, Scholz NL (2004) Defects in cardiac function precede morphological abnormalities in fish embryos exposed to polycyclic aromatic hydrocarbons. Toxicol Appl Pharmacol 196:191-205

Marty GD, Short JW, Dambach DM, Willits NH, Heintz RA, Rice SD, Stegeman JJ, Hinton DE (1997) Ascites, premature emergence, increased gonadal cell apoptosis, and cytochrome P4501A induction in pink salmon larvae continuously exposed to oil-contaminated gravel during development. Can J Zool 75:989-1007

McCarty LS, Munkittrick KR (1996) Environmental biomarkers in aquatic toxicology: fiction, fantasy, or functional? Hum Ecol Risk Assess 2:268-274

Miller MS, Juchau MR, Guengerich FP, Nebert DW, Raucy JL (1996) Drug metabolic enzymes in developmental toxicology. Fundam Appl Toxicol 34:165-175

Mondon JA, Duda S, Nowak BF (2001) Histological, growth, and 7-ethoxyresorufin-o-deethylase (EROD) activity responses of greenback flounder Rhombosolea tapirina to contaminated marine sediment and diet. Aquat Toxicol (Amst) 54:231-247

Moore SF, Dwyer RL (1974) Effects of oil on marine organisms: a critical assessment of published data. Water Res 8: 819-827

Olivry T, Naydan DK, Moore PF (1997) Characterization of the cutaneous inflammatory infiltrate in canine atopic dermatitis. Am J Dermatopathol 19:477-486

Parker RR (1971) Size selective predation among juvenile salmonid fishes in a British Columbia inlet. J Fish Res Board Can 28:1503-1510

Rice SD, Thomas RE, Carls MG, Heintz RA, Wertheimer AC, Murphy ML, Short JW, Moles A (2001) Impacts to pink salmon following the 'Exxon Valdez' oil spill: persistence, toxicity, sensitivity, and controversy. Rev Fish Sci 9:165-211

Sarasquete C, Segner H (2000) Cytochrome P4501A (CYP1A) in teleostean fishes: a review of immunohistochemical studies. Sci Total Environ 247:313-332

Editorial responsibility: Otto Kinne (Editor-in-Chief), Oldendorf/Luhe, Germany
Short JW, Jackson TJ, Larsen ML, Wade TL (1996) Analytical methods used for the analyses of hydrocarbons in crude oil, tissues, sediments, and seawater collected for the natural resource damage assessment of the 'Exxon Valdez' oil spill. Am Fish Soc Symp 18:140-148

Smirnov AI (1975) The biology, reproduction and development of the Pacific salmon. Izdatel'stvo Moskovskogo Universiteta, Moscow. Fish Res Board Can Transl Ser 3861 (translated from Russian)

Snedecor GW, Cochran WG (1980) Statistical methods, 7th edn. Iowa State University Press, Ames, IA

Stagg RM, Rusin J, McPhail ME, McIntosh AD, Moffat CF, Craft JA (2000) Effects of polycyclic aromatic hydrocarbons on expression of CYP1A in salmon (Salmo salar) following experimental exposure and after the Braer oil spill. Environ Toxicol Chem 19:2797-2805

Stegeman JJ, Schleziger JJ, Craddock KE, Tillitt DE (2001) Cytochrome P450 1A expression in midwater fishes: potential effects of chemical contaminants in remote oceanic zones. Environ Sci Technol 35:54-62

Wertheimer AC, Celewycz AG (1996) Abundance and growth of juvenile pink salmon in oiled and non-oiled locations of western Prince William Sound after the 'Exxon Valdez' oil spill. Am Fish Soc Symp 18:518-532

Wiedmer M, Fink MJ, Stegeman JJ, Smolowitz R, Marty GD, Hinton DE (1996) Cytochrome P-450 induction and histopathology in preemergent pink salmon from oiled spawning sites in Prince William Sound. Am Fish Soc Symp 18: 509-517

Willette M (1996) Impacts of the 'Exxon Valdez' oil spill on the migration, growth, and survival of juvenile pink salmon in Prince William Sound. Am Fish Soc Symp 18:533-550

Woodin BR, Smolowitz RM, Stegeman JJ (1997) Induction of cytochrome P4501A in the intertidal fish Anoplarchus purpurescens by Prudhoe Bay crude oil and environmental induction in fish from Prince William Sound. Environ Sci Technol 31:1198-1205

Submitted: August 19, 2004; Accepted: April 28, 2005

Proofs received from author(s): September 5, 2005 